\title{
Pemberdayaan Pemuda Tanggap Bencana (PENDAB) dalam Implementasi Panduan Risiko Bencana
}

\author{
Husni, Widya Lestari, dan Septiyanti \\ Poltekkes Kemenkes Bengkulu, Jalan Indragiri No. 3 Padang Harapan, Bengkulu, 38225. Indonesia \\ E-mail: husniyus2012@gmail.com
}

Keywords: disaster risk, empowerment, youth

Kata Kunci: pemberdayaan, pemuda, risiko bencana

\begin{abstract}
Bengkulu is one of the vulnerable disasters areas. Flood is one of disaster that often occurs in the Bengkulu city. The big flood that occurred at the end of 2019 which claimed the lives of 29 people and 13 people were missing. The aim was to increase the capacity of youth in disaster risk management. Activities done through socialization, disaster training, simulation and disaster risk mapping. Socialization done to stakeholders, youth and community leaders. Disaster risk training, the first aid training for youth and making of organization of Youth Responding to Disasters (PENDAB) have done using lecture, discussion, question and answer methods and doing simulation Table Top Exercise (TTX) for disaster management in the neighborhood Association (RT). The training was attended by 15 youths and was conducted in an open field for 2 days while still observing health protocols. This activity has received permission from the Bengkulu Province Covid-19 task force. The results of the training showed that there was an increase in the knowledge and skills of youth about disasters, basic life support (BHD) and first rescue (PP) actions. Youth are expected to apply the knowledge and abilities that have been acquired during the training to provide education about disaster to the community.
\end{abstract}

\section{ABSTRAK}

Bengkulu merupakan salah satu daerah rawan. Banjir merupakan salah satu bencana yang kerap terjadi di wilayah Kota Bengkulu. Banjir besar yang terjadi akhir tahun 2019 dengan menelan korban jiwa sebanyak 29 orang dan 13 orang dinyatakan hilang karena terbawa arus. Tujuan kegiatan pengabdian masyarakat ini adalah untuk meningkatkan kemampuan pemuda dalam manajemen bencana. Kegiatan dilakukan melalui sosialisasi, pelatihan siaga bencana, simulasi bencana serta pemetaan risiko bencana. Kegiatan sosialisasi dilakukan kepada stakeholder, pemuda dan tokoh masyarakat. Kegiatan pelatihan pengurangan risiko bencana dan pertolongan pertama untuk pemuda dan pembentukan Pemuda Tanggap Bencana (PENDAB) dilakukan dengan metode ceramah, diskusi, tanya jawab dan simulasi, simulasi Table Top Exercise (TTX) penanggulangan bencana di Rukun Tetangga (RT). Pelatihan diikuti oleh 15 orang pemuda yang dilakukan secara tatap muka di lapangan terbuka di wilayah RT 23 Kelurahan Sawah Lebar Baru yang berlangung selama 2 hari dengan tetap memperhatikan protokol kesehatan. Kegiatan ini telah mendapat ijin dari satgas Covid-19 Provinsi Bengkulu. Materi pelatihan meliputi materi kebencanaan, Bantuan Hidup Dasar (BHD) dan Pertolongan Pertama (PP). Hasil pelatihan didapatkan terjadi peningkatan pengetahuan dan keterampilan pemuda tentang kebencanaan, tindakan BHD dan PP. Pemuda diharapkan mengaplikasikan pengetahuan dan kemampuan yang telah diperoleh selama pelatihan untuk memberikan edukasi tentang kebencanaan kepada masyarakat. 


\section{PENDAHULUAN}

Bencana alam merupakan suatu fenomena alam yang terjadi secara langsung maupun tidak langsung mengganggu kehidupan manusia. Kota Bengkulu merupakan salah satu wilayah di Indonesia yang memiliki tatanan geologi sangat kompleks. Indonesia berada pada pusaran tiga lempeng tektonik aktif (lempeng Eurasia, Indoaustralia, dan Pasifik) dunia yang kemudian menempatkan Indonesia sebagai salah satu negara yang paling rawan bencana di dunia. Selama kurun waktu 15 tahun (2004-2009) telah terjadi kurang lebih 24,635 bencana alam yang tercatat pada data BNPB, serta memberikan dampak kepada kurang lebih 40 juta orang dengan 300 ribu orang diantaranya meninggal dunia dan hilang (BNPB, 2019).

Selain bencana gempa, banjir merupakan salah satu jenis bencana yang kerap terjadi di wilayah Kota Bengkulu. Banjir merupakan fenomena alam yang umumnya terjadi pada musim penghujan. Setiap sungai berpotensi banjir. Banjir merupakan peristiwa atau rangkaian peristiwa yang mengancam dan mengganggu kehidupan dan penghidupan masyarakat sehingga mengakibatkan timbulnya korban jiwa manusia, kerusakan lingkungan, kerugian harta benda, dan dampak psikologis (BNPB, 2019). Banjir besar di Propinsi Bengkulu yang terjadi terakhir pada tahun 2019 yang menelan korban jiwa sebanyak 29 orang dan 13 orang dinyatakan hilang karena terbawa arus (Nofirman, 2020).

Penyebab utama timbulnya banyak korban jiwa adalah kurangnya pengetahuan masyarakat tentang tanggap bencana dan kurangnya kesiapan masyarakat dalam mengantsipasi bencana tersebut. Kesiapsiagaan merupakan tindakan yang dilakukan pada masa pra bencana (sebelum terjadi bencana). Tujuannya untuk mengurangi risiko (dampak) yang diakibatkan adanya bencana. Paling tidak ada interaksi empat faktor utama yang dapat menimbulkan bencanabencana tersebut menimbulkan banyak korban dan kerugian besar yaitu: kurangnya pemahaman terhadap karakteristik bahaya (hazards), sikap atau perilaku yang mengakibatkan penurunan sumberdaya alam (vulnerability), kurangnya informasi/peringatan dini (early warning) yang menyebabkan ketidaksiapan, dan ketidakberdayaan/ketidakmampuan dalam menghadapi ancaman bahaya (BNPB).

Kesiapsiagaan adalah bagian yang integral dari pembangunan berkelanjutan. Kesiapsiagaan adalah serangkaian kegiatan yang dilakukan untuk mengantisipasi bencana melalui pengorganisasian serta melalui langkah yang tepat guna dan berdaya guna (UU RI No.24 Tahun 2007). Faktor yang berperan dalam kesiapsiagaan bencana adalah masyarakat dan pihak pengambil keputusan. Masyarakat memiliki pengetahuan (knowledge), sikap (attitude), dan perilaku (behaviour) untuk mengukur tingkat kesiapsiagaan.

Kerugian yang dialami akibat bencana yang begitu besar memerlukan aksi nyata untuk mengurangi risiko bencana. Salah satu kelompok penting dalam masyarakat yang perlu diberi kesempatan seluas-luasnya adalah pemuda. Menurut data Badan Pusat Statistik (BPS), melalui Susenas 2018, jumlah total pemuda Indonesia saat ini adalah 63,82 juta atau seperempat dari total penduduk Indonesia. Pemuda adalah sumber daya yang besar baik secara kuantitas dan juga produktivitas dan menjadi salah satu komponen yang sangat potensial untuk mendukung upaya pengurangan risiko bencana di Indonesia maupun di dunia. Peran aktif masyarakat yang hidup dan tinggal di wilayah yang mempunyai kerentanan tinggi terhadap bencana memang sangat penting. Bencana tidak dapat dihindari, tetapi dapat dipelajari penyebab dan risikonya. Pemuda sebagai bagian dari masyarakat dapat mengambil andil dalam kesiapsiagaan bencana.

Minimnya peran pemuda dalam upaya pengurangan risiko bencana di Indonesia disebabkan oleh beberapa faktor diantaranya; 1) kurangnya akses untuk terlibat dalam berbagai aktivitas pengurangan risiko bencana, 2) minimnya pengetahuan kebencanaan yang dimiliki oleh pemuda, 3) kebijakan pemerintah yang belum berpihak kepada anak - pemuda. Oleh karena itu, pemuda perlu dibekali dan diberi ruang untuk terlibat dalam aktivitas terkait penanggulangan 
bencana. Pemerintah, maupun lembaga non pemerintahan perlu terus melibatkan pemuda dalam kegiatan peningkatan kapasitas baik individu maupun kelompok.

Kelurahan Sawah Lebar Baru Kecamatan Ratu Agung Kota Bengkulu merupakan salah satu daerah yang rawan bencana gempa bumi dan juga bencana banjir. Banjir sering melanda setiap musim hujan datang. Salah satu banjir besar yang terjadi pada tangal 28 April 2019, adalah banjir besar yang mencapai ketinggian 1.7 meter yang telah merendam lebih kurang 70 rumah (Rakyat Bengkulu, 2019). Warga masyarakat RW 06 RT 23 Kelurahan Sawah Lebar Baru memiliki jumlah penduduk dengan total dewasa laki-laki dan perempuan yaitu 427 orang $(46,72 \%)$ dengan rincian usia dewasa laki-laki 218 orang $(47,92 \%)$, dan perempuan dewasa 209 orang (45,54\%), usia remaja sebanyak 166 orang (18,16\%), usia anak sekolah 122 orang $(13,35 \%)$, dan balita 80 orang $(8,75 \%)$.

Bagian Barat dari wilayah Kelurahan Sawah Lebar Baru berbatasan langsung dengan Sungai Tanjung Agung. Bila curah hujan tinggi, air sungai akan meluap sehingga mengakibatkan banjir yang berdampak pada korban jiwa dan harta benda. Data dari Puskesmas Sawah lebar didapatkan jumlah penduduk yang meninggal dalam bencana banjir pada Desember 2019 sebanyak 2 orang. Berdasarkan wawancara dengan salah satu warga bahwa kelurahan Sawah Lebar Baru tahun 2019 terkena dampak bencana banjir yakni sebagian besar perabotan rumah rusak karena banjir, 10 orang warga mengatakan dinding rumah retak akibat banjir. Warga mengatakan ketika banjir, proses evakuasi hanya dilakukan oleh masing-masing keluarga dan tidak dikoordinir. Para pemuda di daerah ini saat menghadapi banjir tidak memiliki pengetahuan dan keterampilan namun hanya berdasarkan pengalaman tahun-tahun sebelumnya.

Organisasi pemuda yang baru saja dibentuk di daerah ini adalah karang taruna namun belum melakukan berbagai kegiatan terkait pengurangan risiko bencana. Berdasarkan hasil wawancara pada pemuda, sebagian besar mengatakan belum pernah mendapat pendidikan tentang penanganan pertama saat terjadi bencana banjir khususnya pemuda di RT 23. Kearifan lokal yang dimiliki oleh pemuda-pemuda di Kelurahan Sawah Lebar Baru yaitu memiliki latar belakang budaya saling tolong menolong antar warga, secara sosial ekonomi yang berbeda-beda, namun ada yang menyatukan mereka yaitu bahwa sama-sama hidup dan tinggal di daerah yang mempunyai tingkat kerawanan tinggi banjir.

Peran pemuda dalam kesiapsiagaan bencana ini dapat dilakukan melalui berbagai kegiatan. Kegiatan awal adalah sosialisasi dan pelatihan Pengurangan Risiko Bencana (PRB). Kegiatan sosialisasi dilakukan pada para pemuda dan stakeholder serta tokoh masyarakat untuk melaksanakan program pengurangan risiko bencana yang bertujuan untuk mewujudkan pemuda tangguh dan tanggap terhadap pengurangan risiko bencana untuk mewujudkan masyarakat yang aman dari ancaman bencana. Kegiatan kedua adalah pemetaan partisipatif yang dilakukan dengan meminta masukan dari pemuda dan masyarakat yang bertujuan untuk menghasilkan visualisasi bahaya dan risiko bencana RT 23 Kelurahan Sawah Lebar Baru yang dapat diketahui oleh masyarakat. Kegiatan dilanjutkan dengan simulasi bencana. Kegiatan simulasi bencana dilakukan proses latihan untuk mendewasakan masyarakat dengan tidak lagi menganggap bencana sebagai sesuatu yang menakutkan dan tidak bisa dihindari dan juga menjadikan bencana sebagai bagian dari kehidupan yang dihadapi bersama.

Tujuan Umum kegiatan ini adalah untuk memberdayakan pemuda dalam meningkatkan kemampuan kesiapsiagaan bencana melalui kegiatan "PENDAB" (Pemuda Tanggap Bencana) dengan tujuan khusus: 1) Tersosialisasinya kegiatan kesiapsiagaan bencana kepada pemuda dan masyarakat, 2)Teridentifikasi risiko bencana di Kelurahan Sawah Lebar Kecamatan Ratu Agung Kota Bengkulu, 3)Terjadi peningkatan pengetahuan dan keterampilan pemuda tentang kesiapsiagaan bencana (mengenal bahaya, kerentanan, risiko, bencana, kapasitas dan pengurangan risiko bencana) dan pertolongan pertama serta BHD melalui pelatihan dan media 
edukasi, 4)Terlaksananya kegiatan simulasi Table Top Exercise penanggulangan bencana di RT 23, dan 5)Terbentuknya kelompok Pemuda Tanggap bencana (PENDAB).

\section{METODE}

Lokasi kegiatan pengabdian ini dilakukan di RT 23 RW 06 Kelurahan Sawah Lebar Baru kecamatan Ratu Agung Kota Bengkulu. Peserta yag terlibat dalam kegiatan ini adalah pemuda sebanyak 15 orang. Selain itu, sasaran kegiatan lain adalah tokoh masyarakat, ketua RT, tokoh agama, tokoh pemuda dan unsur Puskesmas. Kegiatan pemberdayaan dibagi dalam tahapan sebagai berikut; 1) Tahap awal dilakukan penjajakan dan koordinasi dengan pihak terkait meliputi pimpinan puskesmas, kepala kelurahan, tokoh pemuda dan aparat desa. Setelah itu tahap persiapan yang dilakukan meliputi penjajakan ke kelurahan Sawah Lebar Kecamatan Ratu Agung dan wilayah RW 06 Kota Bengkulu, persiapan dan pengembangan instrument meliputi persiapan pembuatan instrument pre dan post test, rencana kegiatan pengajaran, bahan/ materi edukasi dan survei awal kondisi lingkungan RW 06; 2)Sosialisasi kegiatan pengabdian kepada masyarakat dengan khalayak sasaran di wilayah kelurahan Sawah Lebar Baru Kota Bengkulu dan kemitraan; 3)Pelatihan Pengurangan Risiko Bencana (PRB), Pelatihan BHD serta Pertolongan Pertama (PP) selama 2 (dua) hari. Sebelum dan setelah pelatihan dilakukan pengukuran pengetahuan peserta menggunakan kuesioner yang terdiri dari 10 pertanyaan; 4) Pembentukan kelompok "pemuda tanggap bencana" (PENDAB), yang diawali dengan identifikasi pemuda calon peserta PENDAB; 5) Simulasi Table Top Exercise (TTX) penanggulangan bencana RT 23; dan 6) Monitoring dan evaluasi program simulasi siaga bencana secara periodik. Hasil kegiatan pelatihan diolah secara secara univariat dan diuji secara statistik menggunakan uji $\mathrm{T}$ untuk melihat pengaruh pelatihan terhadap peningkatan pengetahuan peserta.

\section{HASIL DAN PEMBAHASAN}

Pelaksanaan kegiatan berlangsung dari Juli sampai dengan Oktober 2020 yang diawali dengan kegiatan penjajakan ke Kelurahan Sawah Lebar Baru Kota Bengkulu pada bulan Juli 2020. Kegiatan ini sangat didukung oleh pimpinan setempat yaitu ketua RT 23 dan warga terkhusus pihak pemuda dengan dibuktikan oleh keterlibatan aktif dalam kegiatan pelatihan risiko bencana, penyusunan kelompok pemuda tanggap bencana dan program kegiatan simulasi bencana. Berikut laporan dari tahapan pelaksanaan kegiatan.

\section{Penjajakan dan Koordinasi Kegiatan}

Kegiatan penjajakan dan koordinasi dilakukan pada tanggal 24 - 25 Juli 2020. Penjajakan awal dilakukan langsung pada pihak RW 06. Berdasarkan hasil penjajakan didapatkan bahwa Kelurahan Sawah Lebar kota Bengkulu merupakan lokasi rawan bencana khususnya bencana banjir yang pernah menyebabkan korban jiwa dan kerusakan lingkungan pada tahun sebelumnya. Hasil penjajakan dengan pihak RW 06 kelurahan Sawah Lebar didapatkan rekomendasi bahwa untuk lokasi kegiatan pengabdian masyarakat difokuskan pada RT 23 dikarenakan wilayah RT 23 pernah menjadi daerah yang terendam banjir dan menimbulkan korban jiwa serta kerusakan harta benda. Ketua RW merekomendasikan RT 23 untuk dijadikan lokasi kegiatan pengabdian masyarakat. Alasan pemilihan lokasi ini dikarenakan wilayah RT 23 bebatasan langsung dengan sungai yang pernah meluap dan menimbulkan banjir serta mengakibatkan korban jiwa dan kerusakan harta benda pada tahun 2019. Koordinasi 
dilanjutkan dengan menemui ketua RT 23. Ketua RT menyambut baik dan siap mendukung untuk mensukseskan kegiatan pengabdian masyarakat ini.

\section{Sosialisasi Kegiatan Kesiapsiagaan Bencana}

Sosialisasi kegiatan kesiapsiagaan bencana dilakukan pada tanggal 8 Agustus 2020 . Kegiatan ini dilakukan secara offline yang dihadiri oleh ketua RT, tokoh masyarakat, para pemuda dan pihak puskesmas yang berjumlah sekitar 30 orang yang bertempat di halaman rumah ketua RT 23. Sebelum kegiatan secara tatap muka ini berlansung, tim terlebih dulu melayangkan surat permohonan izin kegiatan pengabdian masyarakat ke kantor Satgas Covid-19 propinsi Bengkulu. Kegiatan sosialisasi ini bertujuan untuk memperkenalkan kepada para pemuda, stakeholder dan tokoh masyarakat program kegiatan pengabdian yang akan dilaksanakan selama 8 bulan di wilayah RT 23. Kegiatan sosialisasi berjalan dengan lancar dan aman yang dihadiri oleh ketua RT 23, perwakilan RT tetangga, tokoh agama, pemuda karang taruna, perwakilan pihak puskesmas dan tim pengabdian masyarakat. Hasil sosialisasi ini adalah adanya komitmen pemuda, tokoh masyarakat untuk mendukung kegiatan pemberdayaan pemuda dalam kesiapsiagaan bencana.

\section{Pelatihan Pengurangan Risiko Bencana}

Pelatihan Pengurangan Risiko Bencana diikuti oleh 15 orang perwakilan pemuda yang dimulai dari tanggal 8 sampai dengan 9 Agustus 2020 di halaman rumah Ketua RT 23. Kegiatan ini diawali dengan pengisian biodata peserta dan pre test pengetahuan untuk mengukur tingkat pengetahuan pemuda tentang kebencanaan yang dapat dilihat pada tabel berikut :

Tabel 1. Distribusi karaktersitik peserta pelatihan

\begin{tabular}{ll}
\hline \multicolumn{1}{c}{ Karakteristik } & n= 25 (\%) \\
\hline Jenis kelamin & $15(100)$ \\
Laki-laki & 0 \\
Perempuan & \\
Usia & $21,53(2,6)$ \\
Mean (SD) & 22 \\
Median & $20,9-22,98$ \\
CI & \\
Pendidikan & $7(46,7)$ \\
Rendah (SD, SMP) & $8(53,3)$ \\
Tinggi (SMA, PT) & \\
Pekerjaan & $5(33,3)$ \\
Bekerja & $10(66,7)$ \\
Tidak bekerja & \\
Status perkawinan & $15(100)$ \\
Kawin & $0(0)$ \\
Tidak kawin &
\end{tabular}

Tabel 1 menunjukkan bahwa usia pemuda rata-rata 21,5 tahun, lebih dari separuh berpendidikan tinggi 8 (53,3\%), sebagian besar 10 (66,7 \%) bekerja dan seluruhnya (100\%) sudah berstatus menikah. 
Tabel 2. Distribusi rerata pengetahuan peserta pelatihan di RT 23 kelurahan Sawah Lebar Baru kecamatan Ratu Agung, kota Bengkulu tahun 2020

\begin{tabular}{|c|c|c|c|c|c|c|}
\hline Variabel & Mean & Median & SD & Min - Max & $\mathrm{CI}$ & P value \\
\hline $\begin{array}{l}\text { Pre test } \\
\text { Pengetahuan }\end{array}$ & 22 & 30 & 16,562 & $0-50$ & $12,83-31,17$ & 0,268 \\
\hline $\begin{array}{l}\text { Post test } \\
\text { Pengetahuan }\end{array}$ & 29,3 & 30 & 10,328 & $10-50$ & $23,61-35,05$ & \\
\hline
\end{tabular}

Tabel 2 menunjukkan bahwa rerata nilai pengetahuan tentang siaga bencana sebelum pelatihan adalah 22 dengan standar deviasi (SD) 16,562 dan sesudah pelatihan yaitu sebesar 29,33 dan standar deviasi (SD) 10,328. Hasil analisis statistik didapatkan adalah p value 0,268 yang dapat diartikan bahwa tidak ada perbedaan yang signifikan rerata pengetahuan sebelum dan setelah diberikan pelatihan siaga bencana. Faktor yang mungkin dapat mempengaruhi hasil pengetahuan ini adalah setengah dari responden (47\%) memiliki pengetahuan dasar (tamat SMP). Selain itu, lingkungan tempat pelatihan dapat mempengaruhi hasil peningkatan pengetahuan. Tempat kegiatan pelatihan dilaksanakan di lingkungan terbuka yang dapat mempengaruhi stimulus peserta untuk menyerap materi yang diberikan. Faktor lain juga dapat disebabkan kurangnya minat baca pemuda dalam mengulang materi yang sudah diberikan sehingga peningkatan pengetahuan masih belum optimal dan materi yang diajarkan adalah materi baru pertama kali dikenal dengan durasi yang singkat yakni selama dua hari. Berdasarkan hasil penelitian yang dilakukan oleh Saptadi dan Djamal (2012) disimpulkan bahwa pelatihan kesiapsiagaan dan kewaspadaan penanggulangan bencana kepada masyarakat setempat membuat warga lebih peduli akan wilayahnya.

\section{Pembentukan Pemuda Tanggap Bencana (PENDAB)}

Setelah kegiatan pelatihan dilanjutkan dengan pembentukan organisasi PENDAB pada hari ketiga pelatihan (9 Agustus 2020) yang terdiri dari 15 orang yang ditetapkan berdasarkan SK Ketua RT 23. Organisasi PENDAB disusun mulai dari ketua, sekretaris, bendahara dan ketua bidang kegiatan. Pembentukan organisasi ini dihadiri oleh pemuda dan Ketua RT 23.

\section{Simulasi Table Top Exercise (TTX) Penanggulangan Bencana RT}

Simulasi TTX ini dilakukan pada sesi akhir kegiatan pelatihan di lapangan terbuka RT 23. Simulasi ini disamping diikuti oleh anggota PENDAB juga diikuti oleh ketua RT dan tokoh masyarakat. Kegiatan ini mensinergikan SOP Penanggulangan Bencana pada semua tingkatan. Hasil dari kegiatan ini menunjukkan bahwa dalam menghadapi bencana, peran masing-masing pengambil keputusan belum sepenuhnya difahami oleh peserta simulasi misalnya Ketua RT, Ketua RW, pemuda dan lainnya. Masih diperlukan simulasi yang intens untuk meningkatkan pemahaman peserta terhadap peran dan fungsi dalam menghadapi bencana.

\section{Monitoring dan Evaluasi Pemantapan Program Simulasi Siaga Bencana}

Monitoring dilakukan pada bulan Oktober 2020 yang meliputi monitoring terhadap kesiapan melaksanakan kegiatan pemuda PENDAB sebagai salah bentuk tindak lanjut dari hasil kegiatan. Hasil dari monitoring dan evaluasi didapatkan belum adanya kegiatan edukasi yang dilakukan oleh pemuda tentang kesiapsiagaan bencana di wilayah RT 23. Hal ini disebabkan karena kurangnya dukungan dari masyarakat untuk meningkatkan pengetahuan tentang bencana. Disamping itu, sulitnya mengumpulkan massa dalam melakukan kegiatan bersama dikarenakan pandemi Covid-19. Hasil penelitian oleh Pangesti (2012) menunjukkan bahwa 99\% 
responden belum mampu mengaplikasikan kesiapan bencana, sehingga diperlukan upaya untuk meningkatkan kesiapan dalam menghadapi bencana yang dapat berupa sosialisasi dan evaluasi.

\section{KESIMPULAN}

Kegiatan kebencanaan tersosialisasi dengan baik kepada pemuda dan stakeholder dan teridentifikasi risiko bencana di RT 23 Kelurahan Sawah Lebar Baru dan terjadi peningkatan pengetahuan dan keterampilan pemuda tanggap bencana (PENDAB) dan terselenggaranya kegiatan simulasi TTX penanggulangan bencana RT dan terbentuk pemuda tanggap bencana (PENDAB). Hendaknya pemuda bisa berkoordinasi pada tenaga kesehatan setempat secara berkala melakukan simulasi siaga bencana. Puskesmas dapat terlibat dalam memonitoring terlaksananya kegiatan simulasi bencana secara periodik dan perlunya dukungan kegiatan tri dharma perguruan tinggi untuk mensinergikan kegiatan dengan lintas program lainnya.

\section{UCAPAN TERIMA KASIH}

Terimakasih kami sampaikan kepada Direktur Poltekkes Kemenkes Bengkulu yang telah mendanai kegiatan pengabdian masyarakat ini dan terima kasih kepada Ketua RT 23 beserta pemuda dan masyarakat yang telah mendukung terlaksananya kegiatan ini dengan baik

\section{DAFTAR PUSTAKA}

Aisyah, S., Arisanty, D., \& Adyatma, S. (2020). Tingkat Kerentanan Bencana Banjir Di Kecamatan Martapura. Jurnal Pendidikan Geografi, 7(2), 1-10.

BNPB, https://www.bnpb.go.id/potensi-ancaman-bencana

BNPB 2019. Indografis Bencana Banjir dan Longsor Bengkulu Edisi Mei 2019 https://bnpb.go.id/infografis/infografis-bencana-banjir-dan-longsor-bengkulu

Daud, R., Sari, S. A., Milfayetty, S., \& Dirhamsyah, M. (2014). Penerapan Pelatihan Siaga Bencana Dalam Meningkatkan Pengetahuan, Sikap, Dan Tindakan Komunitas Sma Negeri 5 Banda Aceh. Jurnal Ilmu Kebencanaan (Jika), 1(1), 26-34.

Dwiati, T., \& Sukur, M. (2015). Penentuan Tingkat Kerentanan Banjir Secara Geospasial. Jurnal Teknologi Informasi Dinamik, 20(1), 57-76.

Fajri, A. S., \& Widayanti, B. H. (2018). Analisis Kerentanan Daerah Rawan Banjir Berbasis Sistem Informasi Geografis. Jurnal Planoearth, 3(1), 36-43.

Gunawan. (2014). Kesiapsiagaan Masyarakat Dalam Penanggulangan Bencana Kasus Di Kecamatan Cangkringan Kabupaten Sleman - Di Yogyakarta Community. Informasi, 19(2), 91-106.

Hapsoro, A. W., \& Buchori, I. (2015). Kajian Kerentanan Sosial Dan Ekonomi Terhadap Bencana Banjir (Studi Kasus: Wilayah Pesisir Kota Pekalongan). Jurnal Teknik Pwk, 4(4), 542-553. 
Hastanti, B. W., \& Hutapea, F. J. (2020). Analisis Tingkat Kerentanan Terhadap Banjir Bandang Berdasarkan Faktor-Faktor Sosial Ekonomi Dan Kelembagaan Di Wasior, Teluk Wondama, Papua Barat. Jurnal Wasian, 7(1), 25-38.

Nofirman. (2020). Studi Kerentanan Bencana Banjir Di Sungai Air Bangkahulu Provinsi Bengkulu. Jurnal Georafflesia, 4(2), 163-182.

Pangesti, A. D. H. (2012). Gambaran Tingkat Pengetahuan Dan Aplikasi Kesiapan Bencana Pada Mahasiswa Fakultas Keperawatan Universitas Indonesia Tahun 2012. Jurnal Bencana, 1(1), 100-120.

Puspitasari. (2014). Kerentanan Dan Kesiapsiagaan Di Desa Bawak Kecamatan Cawas Kabupaten Klaten Terhadap Bencana Banjir. Jurnal Muhammadiyah, 1(1), 1-8.

Qodriyatun, S. N. (2020). Bencana Banjir: Pengawasan Dan Pengendalian Pemanfaatan Ruang Berdasarkan Uu Penataan Ruang Dan Ruu Cipta Kerja. Jurnal Masalah-Masalah Sosial, 11(1), $29-42$.

Saptadi, G., \& Djamal, H. (2012). Kajian Model Desa Tangguh Bencana Dalam Kesiapsiagaan Penanggula-Ngan Bencana Bersama Bpbd D. I Yogyakarta. Jurnal Penanggulangan Bencana, $3(2), 1-13$.

Suherianti, Mayub, A., \& Farid, M. (2018). Potensi Rawan Banjir Kecamatan Muara Bangkahulu Sebagai Penunjang Pembelajaran Materi Pemanasan Global Di Smpn 11 Kota Bengkulu. Journal Of Science Education, 2(1), 93-98.

UU RI No. 24 Tahun 2007 Tentang Penanggulangan Bencana. 